\title{
Dubai: Changing Forms with Demography
}

\author{
Upama Sen \\ IIT Kharagpur, West Bengal-721302, India
}

"Email: senupama@gmail.com

\section{ARTICLE INFORMATION}

Received: July 16, 2019

Revised: September 10, 2019

Accepted: October 01, 2019

Published online: January 27, 2020

Keywords:

Dubai, Buildings, Sustainable, Architecture,

Transformation

\begin{abstract}
Dubai is a living example of how people play an important role in moulding the shape of a city. It started off as a small settlement in the deserts of the Middle East along a natural creek. The old city is a testament of how the natural growth led to the birth to the vernacular architecture of the region to combat its extreme climate. From a group of fishing villages, Dubai went on to become a hub for global business. It has eventually weaved itself from its people, their culture, traditions, social norms, etc. Its architecture of has undergone dynamic transformation with amazing innovation over the recent decades. Dubai has paced faster than any other city on earth and grew into eminence over a few decades. Built on the Arabian deserts with scarce resources like water, food, building materials, etc, Dubai is now one of the greatest cities in the world. With global warming being a major concern, the world is moving towards a holistic approach of sustainable living. The city has always exhibited its feat of excellence, and is now aimed at becoming the most sustainable city. This paper is an effort to study the architectural styles of the past, their sustainability and how it has evolved though these years. The study is a summary of the vernacular architecture processes that allowed its occupants a comfortable indoor environment in the hot desert conditions.
\end{abstract}

\section{Introduction}

Lying along the south-east coastline of the Persian Gulf, Dubai is the most populous emirate of the United Arab Emirates (UAE). Like most ancient cities and civilizations which flourished along the banks of rivers/sea, Dubai grew along a natural creek. It started as a fishing village and soon became a centre of pearl and sea diving. With the discovery of oil, the city gained much significance. Over the recent decades the city has seen major changes and transformation in its population structure, demography, development pattern and economy. The timeline of this city is extreme in all aspects. The transformation that Dubai has undergone in a mere span of fifty years can be compared to the transformation of pre-industrial western cities to post-industrial ones over centuries. Presently Dubai is a major transportation and business hub of the Middle East. It has also gained immense attention as a tourist destination in the world. Dubai has been a fast-evolving and developing city and has truly emerged as a global city.

\section{Background}

The foundation of the modern Dubai is deep-rooted in its old tribal culture and political scenario. In 1833, the Bani Yas tribe, led by Al Maktoum Family, migrated to this land and settled at the mouth of the creek (Pacione, 2005). Since then the Emirate of Dubai has been ruled by them. Dubai was inhabited by different clans before the Maktoum family took over. It is believed to be a part of the pre-Islamic community led by the Sassanian empire since the $3^{\text {rd }}$ century AD. The Portuguese were the first Europeans to have settled in early Dubai. They were soon followed by others like the French, Dutch and British.

Before its formation, the United Arab Emirates was a collection of sheikhdoms known as the Trucial States. The local rulers were embroiled in rivalries among themselves for centuries and the pirates scoured the seas. Britain, in order to protect its trade links with India, tied up with the Trucial States to fight against piracy. In 1971, six emirates declared their independence from the British and together formed the United Arab Emirates (Gaikwad, 2013). 
Ras al Khaymah joined the federation in February 1972. With the discovery of gold and oil, the economy dramatically changed. In recent decades, the image of the city has transformed with the rise of innumerable majestic skyscrapers. With the best of hotels, malls, entertainment, etc., is presently one of the luxury shopping and holidaying destinations of the world.

\section{Transformation of Dubai}

\subsection{Demography}

Being one of the fastest growing cities, Dubai has seen rapid population growth over time. The population of Dubai was reported to be 3,290,650 in 2018 (Dubai Statistical Center, 2018).

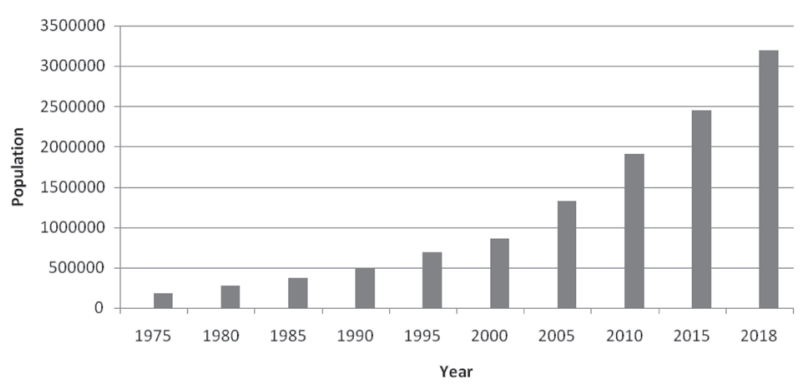

Figure 1: Demographic growth over time (Source: Author).

The political stability, thriving economy and job opportunities serve as the pull factors for people. As per the Dubai Statistics Center, only $7.97 \%$ of the population in 2018 were Emiratis, which indicates that Dubai is home to a lot of immigrants who majorly make up the existing population figure of Dubai (Dubai Statistical Center, 2018).

\subsection{Urban Economy}

Pearl diving and sea trade were the main occupations of the people who settled along the creek. Tax exemption largely drew foreign traders into Dubai. However, with the First World War, the great depression of the 1930 s and the Japanese invention of cultured pearl, the booming pearl business collapsed (Pacione, 2005). In the early $20^{\text {th }}$ century Dubai transformed into an important port city, with the trade and commerce flourishing in the souks on the Deira region. A serious drawback arose once silting of the creek prohibited large ships to enter. The then ruler of Dubai resolved this challenge through an ambitious, visionary project of dredging the creek that eventually reinforced Dubai's position as a major port city. With the discovery of oil in 1966, the economy boomed. The city thereafter underwent several major transformations, from the making of its currency, growth of infrastructure, etc. Transforming into a commodity-based economy gave Dubai a major economic upgrade. It went on to the establishment of the largest harbour. It used its oil resources to build world-class infrastructure that attracted people from all over the globe. With exhausting resources of oil and natural gas, the current largest contributors to the economy are real estate and construction, trade and commerce and port. The Jebel Ali port in Dubai has the largest man-made harbour in the world. Dubai is also a hub from service sector industries like finance and information technology. With special economy zones (SEZ), such industrial development has received a boom. Tourism is an important aspect that contributes to the economy largely.

\subsection{Emerging Cityscape}

Dubai has made a vivid transformation from barren deserts to a global city. If we consider phase-wise growth, the urban from developed as a response to the needs of the immigrants who migrated to Dubai at different time phases. Trade and commerce have played a crucial role in moulding the urban form of Dubai. The housing scenario started changing with the advent of merchants due to the boom of the pearl industry. And post-oil discovery, Dubai saw huge immigration of labourers. Isolated housing for these low wage earners evolved as integrating these people into the existing community was considered indecorous. With the diversification of the economy, Dubai has seen many waves of migration and newer housing patterns have emerged to fulfil the demands. The urbanscape has transformed rapidly with innumerous skyscrapers which stand tall adorning the city. It has undertaken huge projects like the Palm Islands which have changed the map of Dubai completely.

The Dubai Creek flowing southward from the Arabian Gulf divides the emirate into two distinctive regions (Nassar, Blackburn, \& Whyatt, 2014). North of Creek is one of the oldest parts of Dubai and home to its many colourful souks and markets, like the Gold Souk, Spice Souk, and the Deira Fish Market. Historically, Deira has been the commercial center 
of Dubai. Deira has developed much since its early days with recent developments of the metro corridor, shopping malls, towers, etc.

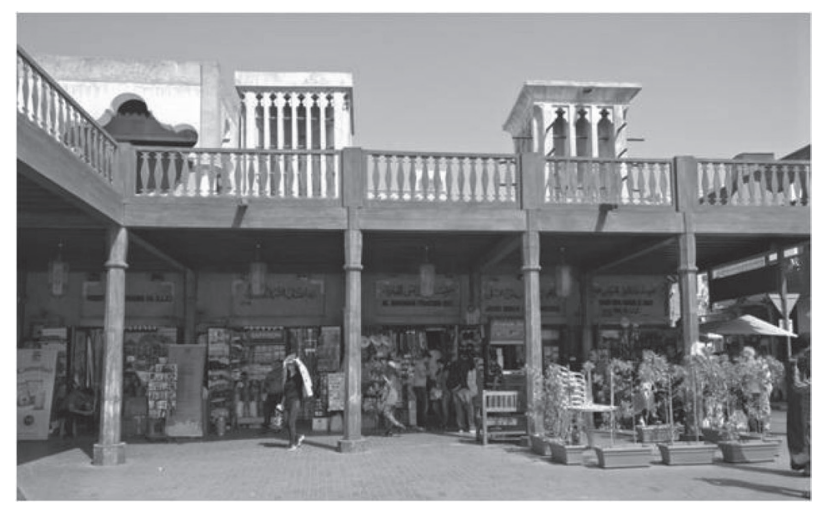

Figure 2: Souks of Deira Dubai (Source: Author).

Bur Dubai lies to the western side of the Dubai Creek. It is a popular living area consisting of several apartment buildings. With the extension of the Dubai Creek back to the sea Bur Dubai has turned into an island. The skyline of modern Dubai is adorned with skyscrapers. The Palm Islands were an ambitious project that have redefined Dubai. The design intended to increase the shoreline of Dubai.

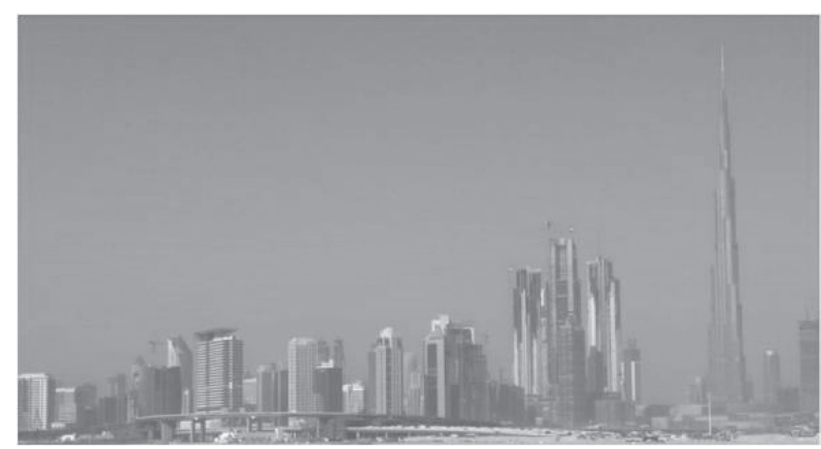

Figure 3: Skyline of Modern Dubai (Source: Author).

The city state is renowned for its urban image, but it still holds on to elements of its traditional Emirati culture. Inaugurated in 2018, the Dubai Frame is a monument that celebrates the past, present and future of Dubai.

\section{Architecture of Dubai}

The visual image that modern Dubai has in the mind of people is that of magnificent buildings made of glass and steel. In its path to modernity, Dubai has left behind its traditional building architecture (Abdelmonem \& Loehlein, 2007).

Dubai lies in the Arabian Desert region and experiences a tropical desert climate. The vernacular architecture or the traditional houses were best suited for the climate and way of living of the people. It made use of very simple local, available and sustainable building materials which adapted well to the climate. The architecture also fulfilled demands of lifestyle, and suited the social and economic context. Made with limited resources, the native homes barred dwellers from the harsh environment.

In the early years of formation of Dubai, its architecture remained entirely traditional, with windtower houses, narrow alleys, etc. which reflects its strong Bedouin heritage. The form of the vernacular homes was totally derived from its functions. Privacy and ventilation were the most important influences on the layout. The rooms opened onto a central courtyard which was restricted only to family use. Kitchens, located at one end of the courtyard, functioned as an eating and sleeping area in the hot summer months. The arrangement increased airflow to the rooms. The traditional layout of these native houses was apt for combatting the extreme climate of the Middle East.

Wind movement is the key element critical to passive cooling. Although the layout and natural materials helped in providing cool interiors, wind catcher towers were also used to improve ventilation. The concept of wind catcher tower was imported from Iran. The wind towers were constructed in an X-shaped design and left open on four sides to catch and push the cooling air to the room beneath (Hawker, 2002).

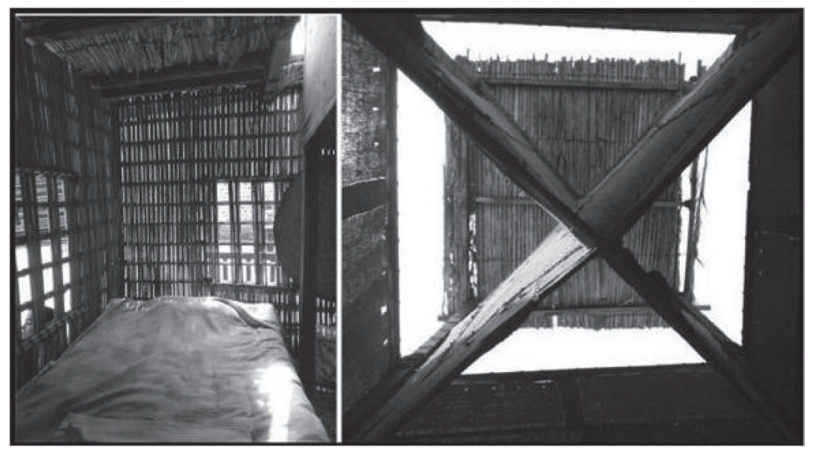

Figure 4: Interiors of tradition vernacular homes of Dubai (left), Windcatcher (right) (Source: Author).

To reduce heat gain, the houses were built very close together forming narrow passages for the high walls to 
provide shade during much of the day. The vernacular architecture used little or no energy and purely by its design created an ambient and comfortable indoor environment.

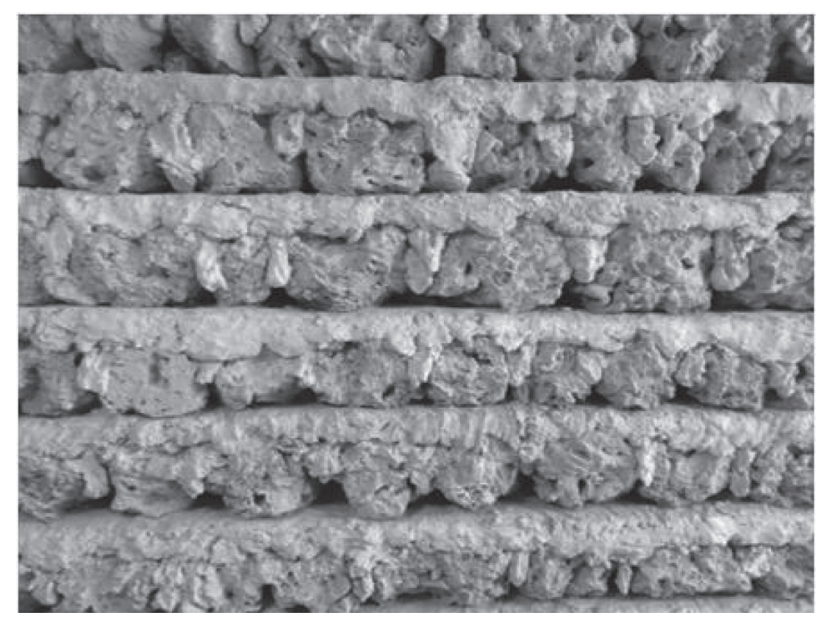

Figure 5: Sheikh Saeed House (Source: Author).

Very few examples of the traditional Emirati architecture still exist for us to see. The Sheikh Saeed House in the Shindagha neighbourhood of Dubai is one of the few buildings from this period that has survived and has been conserved and transformed into a museum. The house was typically built around a central courtyard. Several techniques were implemented for cooling the residence (Hawker, 2002). The Al Fahidi Fort which now has been transformed into a musuem is another example of traditional architecture of the region.

Different groups of people who inhabited in Dubai brought with them their different cultures, traditions, construction methods, etc. which influenced the traditional architecture of Dubai to a lot of extents. The Persian immigration during the $19^{\text {th }}$ century brought a stable construction method using underwater stone and coral obtained from the coastal reefs. Lime deposits found in the estuary was used as mortar for binding the stones. Coral and shells were also burnt to be used as lime for plastering the walls.

The traditional materials of construction were mud, stone, wood, thatch and coral. Palm wood planks or mangrove beams were commonly used to support the ceiling. With discovery of oil, the new chapter in the economic transformation of the UAE began. Concrete replaced the traditional building materials. And with time the pattern of the settlements changed to modern day blocks (Hawker, 2002).

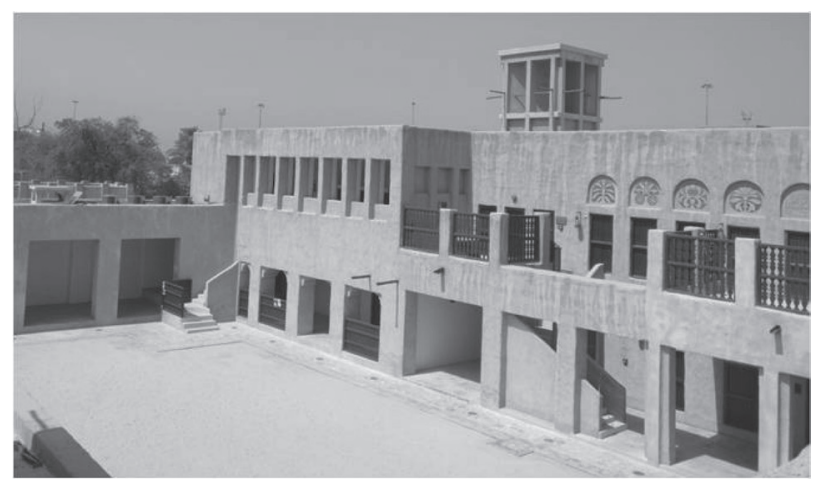

Figure 6: Coral masonry with lime mortar wall (Source: Author).

Modern-day Dubai is renounced for its ultramodern luxury, lifestyle, skyscrapers, etc. The city is adorned by skyscrapers, explicitly by Burj Khalifa, the tallest building on earth till date. The Dubai Frame, Dubai Fountain and the Dubai Mall are a few compelling tourist attractions in Downtown Dubai. The modern architecture for which Dubai and other UAE cities are famous today was created post 1980. It uses curtain walls and glass facades extensively. With the world's tallest and most luxurious hotels, innumerable shopping malls, a vivid range of adventures and entertainment, Dubai has become the ultimate tourist destination in recent times. The Dubai World Trade Center is among the earliest skyscraper in Dubai. The $828 \mathrm{~m}$ tall Burj Khalifa in Dubai not only hold the world record of tallest building on earth but also the tallest free-standing structure in the world, building with highest number of storeys, highest occupied floor, and many other (Burj Khalifa). Another noteworthy mention is the Burj-al-Arab hotel which is located on an artificial island in Dubai. Since early 1990s, the glass towers, all of which fed on massive amount of electricity became the prominent features in the city state of Dubai. These constructions in Dubai city paid quite little heed to the concerns of the environment; neither it paid attention to its traditional Islamic architecture. However in the last decade the development have been harmonius mostly taking care of environmental concerns as well as their traditional heritage.

Dubai faces an extreme shortage of water and simultaneously ranks among the major consumers of water worldwide. The magnificent towers of steel and glass heavily rely on air conditioning systems for their cooling needs. They demand an enormous quantity 
of electricity to support their large illumination and HVAC systems. Intensive use of natural gas and fossil fuel for this purpose is quite untenable. Burj Khalifa, by itself, is assumed to consume 946,000 litres of water/day (Belleza, 2010). Buildings release carbon dioxide and other greenhouse gases which is among the major causes of global warming. With the rise of the sea levels due to global warming, flooding can be a major threat to Dubai. It's oil reserves are expected to be exhausted within the next few years.

\section{Sustainability in Dubai}

Today, UAE ranks amongst the top in the least environmental friendly countries. Lying in the Arabian desert region, Dubai's topography mostly comprises of barren deserts and it experiences tropical desert climate with scarce precipitation. Rapid urbanization has led to many issues related to the environmental, dearth of basic resources such as food, water, building materials, etc. To meet the crisis of water, Dubai makes use of an energy-intensive method of desalination of seawater. Dubai would be facing a major crisis in the near future if it does not embrace a sustainable approach towards development to create a correct balance between economic development and the environment.

The climatic condition of Dubai demands an ecological model that produces an optimal comfortable interior environment by decreasing the high humidity and temperature. However, the modern buildings function quite opposite to this. The skyscrapers with long glass facades and thin skin allow maximum heat gain and heavily depend on intensive air conditioning system for cooling purposes. The Dubai municipality made green buildings regulations obligatory for governmental buildings in 2011, which was later mandated for all upcoming buildings in Dubai. Adaptation of traditional building materials or new materials with similar properties and methods to match contemporary benchmark would be a sustainable choice in building construction.

The Emirate recently launched the Dubai Clean Energy Strategy, which aims to achieve a $75 \%$ share of clean energy in the total mix by 2050 . The city will be hosting the Expo 2020, the theme is sustainable, and is currently focused on transforming itself into the most sustainable city in the world.

\section{Conclusions}

Dubai has experienced a dramatic transformation over the last few decades. From a pearl diving and regional sea trade centre it has evolved to be an eminent global city. The transformation brought about a paradigm change in architectural styles, construction technology, etc. Unlike the native vernacular buildings, the modern development scenario of Dubai is quite energy extensive. It is quite a challenge to build a sustainable city on the sand with scarce resources. But with continuous immigration, the population growth in UAE is among the highest in the world. To protect the environment for the later generations and provide people with better living conditions Dubai has already taken its preliminary steps towards sustainable and energy-efficient development. Hence, the need to build sustainable cities is no more a choice but an immediate necessity. There is a huge scope of research on sustainable architecture using the techniques or concepts from the native built forms to serve modern-day needs.

\section{Acknowledgement}

I would like to thank Prof. (Dr.) K Mohan for always being an inspiration.

\section{References}

Abdelmonem, M. G., \& Loehlein, G. (2007). Sustainability in Traditional Houses in the UAE: Potentials and improvement of buildings abilities. The Second International conference of Dubai Conservation.

Belleza, I. E. (2010). Burj Khalifa: Towering challenge for builders. Retrieved 11 25, 2018, from Gulf News: www.gulfnews.com.

Burj Khalifa. (n.d.). Retrieved 11 25, 2018, from www. burjkhalifa.ae.

Dubai Statistical Center. (2018). Number of Population Estimated by Nationality. Dubai Statistical Center.

Dubai Statistical Center. (2018). Population by gender. Dubai Statistical Center.

Dubai Statistics Center. (2018). Population by Gender and Age Groups. Dubai Statistics Center.

Gaikwad, R. (2013). 10 Interesting Facts About Dubai History. Retrieved 12 20, 2018, from Raynatours: blog.raynatours.com.

Government of Dubai. (2016). A Sustainable Dubai The Dubai Municipality Report. 
Hawker, R. W. (2002). “Where’s the air conditioning switch?”: Identifying problems for sustaining local architectural traditions in the contemporary United Arab Emirates'. In C. A. Brebbia, J. F. Martin- Duque, \& L. C. Wadhwa, The Sustainable City II (pp. 449-464).

Nassar, A. K., Blackburn, G. A., \& Whyatt, D. (2014). Developing the desert: the pace and process of urban growth in Dubai. Computers, Environment and Urban Systems, 45, 50-62.

https://doi.org/10.1016/j.compenvurbsys.2014.02.005
Pacione, M. (2005). City profile Dubai. Cities, 22(3), 255-265.

https://doi.org/10.1016/j.cities.2005.02.001

The official portal of Dubai government. (n.d.). Retrieved 09 10, 2019, from www.dubai.ae.

Tristam, P. (2019). United Arab Emirates History and Independence. Retrieved 11 12, 2018, from Thought Co.: www.thoughtco.compaper.

\section{旬 \\ CHITKARA}

\section{Creative Space}

Chitkara University, Saraswati Kendra, SCO 160-161, Sector 9-C, Chandigarh, 160009, India

\section{Volume 7, Issue 2}

January 2020

ISSN 2321-3892

Copyright: [` 2020 Upama Sen] This is an Open Access article published in Creative Space (Creat. Sp.) by Chitkara University Publications. It is published with a Creative Commons Attribution- CC-BY 4.0 International License. This license permits unrestricted use, distribution, and reproduction in any medium, provided the original author and source are credited. 